\title{
Initial therapy of bacterial meningitis with cefuroxime: Experience in 167 children
}

\author{
LISSETTE NAVAS, MD, SUSAN M KING, MDCM, RONALD GOLD, MD
}

\begin{abstract}
L NAVAS, SM KING, R GoLD. Initial therapy of bacterial meningitis with cefuroxime: Experience in 167 children. Can J Infect Dis 1992;3(4):162-166. The morbidity and mortality of patients with bacterial meningitis treated initially with cefuroxime were studied and compared with the results of a previous prospective study of patients treated initially with ampicillin plus chloramphenicol in the same institution from 1979 to 1983. A retrospective chart review was completed in all cases of microbiologically confirmed bacterial meningitis admitted to the Hospital for Sick Children in Toronto, Ontario between January 1. 1984 and August 1, 1988. During this period all patients were treated initially with intravenous cefuroxime. The 167 children reviewed ranged in age from six weeks to 17.1 years (median 11.6 months). The case fatality rate was $7.8 \%$ and the rate of hearing deficit $13 \%$. There were no statistically significant differences in abnormal neurological outcome (20 versus $20 \%$, respectively), hearing loss (12.9 versus $13 \%$, respectively), and case fatality rate (6.4 versus $7.8 \%$, respectively) between the cohort of 1979 - 83 and the present study. The rate of hearing loss following meningitis caused by Haemophilus influenzae type b increased from 7.3 to $11.7 \%(\mathrm{P}=0.26)$.
\end{abstract}

Key Words: Bacterial meningitis. Cefuroxime, Pediatric

\section{Traitement initial de la méningite bactérienne par le céfuroxime: Expérience chez 167 enfants}

RÉSUMÉ: On a étudié la morbidité et la mortalité des patients porteurs de méningite bactérienne initialement traités par le céfuroxime et on les a comparées aux résultats d'une étude prospective antérieure où les patients avaient été traités par l'ampicilline et le chloramphénicol dans le même établissement, de 1979 à 1983. Lanalyse rétrospective des dossiers a été effectuée dans tous les cas de méningite bactérienne confirmée microbiologiquement chez les enfants hospitalisés au Hospital for Sick Children de Toronto (Ontario), du ler janvier 1984 au 1er août 1988. Au cours de cette période, tous les patients avaient été traités initialement sous céfuroxime administré par voie intraveineuse. Les 167 enfants étudiés étaient âgés de six semaines à 17,1 ans (médiane 11,6 mois). Le taux de létalité était de 7,8\% et le taux de pertes de l'audition de $13 \%$. On ne relève aucune différence statistique significative dans les résultats neurologiques anormaux (20\% contre $13 \%)$ et la létalité (6,4 contre 7,8\%) entre la cohorte de 1979 à 1983 et la présente étude, respectivement. Le taux de séquelles auditives attribuables à la méningite due à Haemophilius influenzae de type b est passé de 7,3 à $11,7 \%(\mathrm{P}=0,26)$.

Division of Infectious Disease, Department of Pediatrics, The Hospital for Sick Children: and Faculty of Medicine. University of Toronto, Toronto, Ontario

Correspondence and reprints: Dr Ronald Gold, Division of Infectious Diseases, Department of Pediatrics. Hospital for Sick

Children, 555 University Avenue, Toronto. Ontario M5G 1X8. Telephone (416) 598-6273

Received for publication May 16, 1991. Accepted August 30. 1991 
A CUTE BACTERIAL MENINGITIS HAS AN INCIDENCE OF 27 TO 100 per 100,000 per year in children younger than five years of age (1). The case fatality rate is 5 to $20 \%$, depending on etiology and age $(1,2)$. Between 25 and $50 \%$ of survivors suffer long term morbidity $(3,4)$. More recent reports have shown less severe consequences of disease. Fourteen per cent of the survivors of bacterial meningitis and $18 \%$ of Haemophilus influenzae type b meningitis survivors suffered long term morbidity $(5,6)$. Hearing loss, language disorders, impaired vision, developmental delay, mental retardation, motor deficits and seizures are the most frequent problems. Hearing impairment is reported in 10\% of cases (range 5 to 30\%) (5-7). Cefuroxime therapy of meningitis due to $H$ influenzae type $\mathrm{b}$ has been reported to be associated with both delayed sterilization of cerebrospinal fluid (CSF) and an increased frequency of hearing impairment $(8,9)$.

At the Hospital for Sick Children in Toronto, Ontario during the period July 1, 1984 to March 1, 1989, cefuroxime was used for initial therapy of all patients admitted with a diagnosis of bacterial meningitis. The medical records of all patients with bacterial meningitis were reviewed to determine whether there was any increase in morbidity or mortality in children treated initially with cefuroxime, compared with a previous prospective study from 1979-83 from the same institution treated with a different antibiotic regimen (10).

\section{PATIENTS AND METHODS}

All patients with microbiologically confirmed bacterial meningitis admitted to the authors' hospital between January 1, 1984 and August 1, 1988 were included in the present study. Cases were identified by review of discharge diagnoses in the health record library and of bacterial cultures of the CSF in the bacteriology department. A patient was considered to have bacterial meningitis if CSF culture was positive for $H$ influenzae type b, Streptococcus pneumoniae or Neisseria meningitidis, or if the antigens of one of the above pathogens were detected in the CSF by latex agglutination, or if the blood culture was positive and the white blood cell count in CSF was greater than $1000 / \mathrm{mm}^{3}$. The information collected in this retrospective chart review included: age, race, sex, culture results, death and presence of sequelae at discharge and at follow-up.

During this period, all patients admitted with a diagnosis of bacterial meningitis were treated initially with intravenous cefuroxime (225 mg/ kg/day). Therapy was changed to ampicillin or penicillin if susceptible bacteria were identified. If an ampicillin-resistant strain of $H$ influenzae type b was isolated, cefuroxime was continued. Uncomplicated cases of meningitis received a seven day course of antibiotics (10).

All patients were scheduled to have a follow-up visit one month post discharge, at which time an interval history and physical examination were performed.
Hearing was evaluated by means of sound field or visual reinforcement audiometry, depending on the child's age. Hearing impairment was classified as follows: mild to moderate, no response at 26 to $55 \mathrm{~dB}$; moderately severe to severe, no response at 56 to $90 \mathrm{~dB}$; and profound, no response at $91 \mathrm{~dB}$ or greater. If a hearing problem was detected or if the test was inconclusive because of young age or lack of cooperation, the patient was followed every three months in the otolaryngology clinic. Neurodevelopmental and psychological assessments were also scheduled for all patients. The neurodevelopmental evaluation was done in the pediatric neurology clinic within 12 months of discharge. Neurological parameters were evaluated by clinical assessment. Investigations such as electroencephalography and computed tomography scans were only performed if clinically indicated. A psychometric evaluation was performed after two years of age in infants and within the six months after discharge in older children. The psychological tests applied were the VinelandGriffith and the Bayley Scale Development for children younger than 2.5 years of age, and the Stanford-Binet test for children between two and four years of age. For children older than five years the Wide Range Achievement Test and the Wechsler Intelligence Scale were performed. A test was considered abnormal when the score was minus one standard deviation from the mean of 100 (standard deviation 14 to 16 ).

Results are expressed in means and proportions and, when appropriate, differences between groups were tested with the $\chi^{2}$ test.

\section{RESULTS}

One hundred and sixty-seven infants and children with bacterial meningitis were included in the study. Meningitis was caused by $H$ influenzae type b in 111 patients (63.3\%), Strep pneumoniae in 31 (18\%), and $N$ meningitidis in 25 (14.3\%). One hundred and fifty-five patients were admitted directly from the clinic or emergency department; 12 were transferred after several days of treatment in other hospitals. The ages ranged from six weeks to 17.1 years, with a mean age of 28.3 months (median 11.6). In patients with $H$ influenzae meningitis, the median age was 12 months, and $70 \%$ were younger than 18 months (Table 1).

The case fatality rate was $7.8 \%$ (13 of 167). The age of the patients who died was between 2.2 and 54.8 months (median 17.8). The fatality rates of meningitis due to $H$ influenzae and Strep pneumoniae were 9.0 and $9.6 \%$, respectively. No death occurred in the 25 patients with meningococcal meningitis. Of the 13 patients who died, nine were brain dead on arrival at the authors' hospital and four were in shock and died within $48 \mathrm{~h}$.

Of the 12 patients transferred from other centres four received more than $24 \mathrm{~h}$ of antibiotic treatment 
TABLE 1

Characteristics of patients with bacterial meningitis treated at the Hospital for Sick Children (Toronto, Ontario) 1984-88

\begin{tabular}{|c|c|c|c|c|}
\hline Characteristic & Haemophilus influenzae & Streptococcus pneumoniae & Neisseria meningitidis & Total \\
\hline Number & 111 & 31 & 25 & 167 \\
\hline Mean age (months) & 18.0 & 44.3 & 41.4 & 28.3 \\
\hline Median age (months) & 11.7 & 10.6 & 10.3 & 11.6 \\
\hline \multicolumn{5}{|l|}{ Race } \\
\hline Caucasian & 105 & 29 & 22 & 156 \\
\hline Black & 4 & 2 & 3 & 9 \\
\hline
\end{tabular}

TABLE 2

Outcome of bacterial meningitis in 123 children initially treated with cefuroxime and followed for at least nine months

\begin{tabular}{|c|c|c|c|c|}
\hline Outcome & Haemophilus influenzae & $\begin{array}{l}\text { Streptococcus } \\
\text { pneumoniae }\end{array}$ & Neisseria meningitidis & Total \\
\hline Death $(\%)$ & 9.0 & 9.6 & 0.0 & 7.8 \\
\hline Followed for at least nine months & 85 & 23 & 15 & 123 \\
\hline At least one abnormality (\%) & 21.1 & 17.4 & 20.0 & 20.3 \\
\hline \multicolumn{5}{|l|}{ Hearing impairment } \\
\hline Speech delay (\%) & 10.5 & 4.3 & 6.6 & 8.9 \\
\hline Motor deficit (\%) & 10.5 & 0 & 6.6 & 8.1 \\
\hline Hydrocephalus (\%) & 3.5 & 4.3 & 0 & 3.2 \\
\hline Epilepsy (\%) & 2.3 & 4.3 & 0 & 2.4 \\
\hline Visual deficit (\%) & 3.5 & 0 & 0 & 2.4 \\
\hline
\end{tabular}

before admission. All four cases had $H$ influenzae meningitis. They were followed for more than one year, and only one case with a mild learning disability was detected. These four patients have been excluded from the long term neurodevelopmental assessment (Table 2).

Of the 154 patients who survived, 123 (80\%) were followed for more than nine months. One or more long term neurodevelopmental sequelae was documented in 25 patients (20.3\%) (Table 2). Twenty-one per cent of patients with $H$ influenzae meningitis followed for nine months or more had one or more neurodevelopmental sequelae. Morbidity rates in the patients with meningitis caused by $N$ meningitidis and Strep pneumoniae were 20 and 17\%, respectively (Table 2). Hearing impairment was the most common sequela, occurring in $13 \%$. Hearing loss was moderate to severe in $3.2 \%$, and bilateral profound in $5.7 \%$ of the survivors.

Of the 27 patients who did not complete nine months of follow-up, 22 were normal at the time of discharge and were followed by their family physicians. Three had sequelae documented approximately six months after discharge: hypotonia, speech delay and unilateral mild hearing deficit, respectively. Two patients had sequelae at the time of discharge: speech delay in one and hyperactivity in the other. Of the 27 patients who did not have long term follow-up, 10 had meningococcal meningitis. Five of these had a normal hearing test one month after discharge. Follow-up was significantly less frequent in patients with meningococcal meningitis than in those with meningitis caused by $H$ influenzae or Strep pneumoniae $\left(\chi^{2} 10.33, \mathrm{P}<0.005\right)$.

In order to determine whether there was any increase in the mortality or morbidity of bacterial meningitis in children who were treated initially with cefuroxime, findings were compared with those of a previous prospective study at the Hospital for Sick Children from 1979 to 1983 at a time when initial therapy consisted of ampicillin plus chloramphenicol (10). This study included 171 patients with acute bacterial meningitis followed for more than one year. $H$ influenzae was isolated in 124 cases, Strep pneumoniae in 30 and $N$ meningitidis in 17 . The mean age was 26.4 months (range four days to 18 years); $74 \%$ of patients were younger than two years.

There was no difference in abnormal outcome during long term follow-up between the two time periods (Table 3). Hearing loss following $H$ influenzae meningitis had a tendency to increase $-11.7 \%$ (10 of 85 ) compared to $7.3 \%$ (nine of 124) observed in the ampicillin-chloram. phenicol group - but the difference was not statistically significant $\left(\chi^{2} 1.23, \mathrm{P}=0.26\right)$. (Assuming a type 1 error [alpha] of 0.05 and the sample size for each group - the type 2 error [beta] is $50 \%$.) 


\section{DISCUSSION}

The Hospital for Sick Children has had an established post meningitis follow-up protocol since 1979. All patients in both cohorts were evaluated using the same criteria for hearing test and neurodevelopmental assessment. There was no change in the referral pattern from other hospitals during the late study period versus 1979-83.

The distribution of etiological agents and the age distribution of patients in both cohorts were similar to those described in the literature (9-14). Two-thirds of the present cases were caused by $H$ influenzae type b, and the median age was 11.6 months. As expected, the rate of $H$ influenzae type b beta-lactamase positive isolates from sterile sites in the authors' centre was slightly different in the two groups: $22 \%$ (59 of 271) for the period $1979-83$, and $29.5 \%$ (75 of 254) for the period 1984-88 ( $\left.\chi^{2} 4.149, \quad \mathrm{P}=0.041\right)$ (personal communication).

There was no statistically significant difference in case fatality rate (6.4 versus $7.8 \%$ ), incidence of hearing impairment (12.9 versus $12.5 \%$ ), and occurrence of long term sequelae (20 versus $20 \%$ ) between the previous study with ampicillin plus chloramphenicol as initial therapy (1979-83) and the present study (198488) from the same centre. All 167 patients received cefuroxime during the initial 48 to $72 \mathrm{~h}$ of therapy. There was an increase in the incidence of hearing impairment when cefuroxime was used as initial therapy, but the difference from the ampicillin plus chloramphenicol cohort was not statistically significant. Cefuroxime has been associated with delayed sterilization of CSF after 18 to $36 \mathrm{~h}$ of therapy, a higher rate of neurological deficit at the time of discharge, and hearing loss at six weeks of follow-up post discharge, when compared with a third generation cephalosporin $(8,9)$. Delayed sterilization of $\mathrm{CSF}$ has been reported in patients treated with ampicillin, carbenicillin, ceftizoxime and ceftazidime, in addition to cefuroxime (15). A second lumbar puncture after 24 to $48 \mathrm{~h}$ is not standard practice in the present authors' institution. Of the 123 patients with complete follow-up none had a documented relapse of the illness. Risk factors associated with delayed sterilization of CSF included isolation of $H$ influenzae and age less than six months $(8,15)$. In the later study population, $H$ influenzae occurred in $66 \%$ of cases, and $24 \%$ of patients (27 of 111) were younger than six months of age. One patient in this age group developed a hearing deficit (3.7\%).

Although the present study is not a controlled trial, the potential biases in a consecutive cohort study have been addressed. These are: change in referral pattern; type of management and follow-up protocol; age; and etiological agent distribution; as well as the proportion of beta-lactamase positive isolates of $H$ influenzae. A trend towards increased hearing impairment in patients with $H$ influenzae type $\mathrm{b}$ meningitis treated
TABLE 3

Outcome of bacterial meningitis in children treated initially with ampicillin plus chloramphenicol compared to cefuroxime

\begin{tabular}{lcc}
\hline & $\begin{array}{c}\text { Ampicillin + } \\
\text { chloramphenicol } \\
\text { Outcome }\end{array}$ & $\begin{array}{c}\text { Cefuroxime } \\
(1979-83)\end{array}$ \\
\hline Number & 171 & 123 \\
Death (\%) & 6.4 & 7.8 \\
At least one abnormality (\%) & 20.5 & 20.3 \\
Total hearing impairment (\%) & 12.9 & 13.0 \\
Haemophilus influenzae & 7.3 & $11.7^{\star}$ \\
\hline
\end{tabular}

${ }^{*} \chi^{2}$ 1.23, $P=0.265$

\section{TABLE 4}

Moderate to profound hearing impairment post acute bacterial meningitis in three different cities

\begin{tabular}{lcccc}
\hline & & \multicolumn{2}{c}{ Hearing impairment } \\
$\begin{array}{l}\text { City } \\
\text { (reference) }\end{array}$ & Steroids & Study & $\begin{array}{c}\text { Cefuroxime } \\
\text { n (\%) }\end{array}$ & $\begin{array}{c}\text { Ceftriaxone } \\
\text { n (\%) }\end{array}$ \\
\hline Berne (9) & No & 106 & $9(17)$ & $2(3.8)$ \\
Dallas (14) & Yes & 122 & $9(12.3)$ & $4(8.2)$ \\
Dallas (14) & No & 165 & $16(24)$ & $12(12)$ \\
Toronto* & No & 123 & $11(8.9)$ & \\
\hline
\end{tabular}

n Number of patients; * Present study

initially with cefuroxime was detected. Although the increase in hearing loss did not reach statistical significance, because of the association reported between the use of cefuroxime and the occurrence of delayed sterilization of the CSF and deafness, cefuroxime is no longer recommended for treatment of bacterial meningitis in children $(16,17)$. The incidence of moderate to profound hearing impairment post acute bacterial meningitis in Toronto seems to be lower than in other centres $(9,14)$ (Table 4). Factors other than antibiotic regimen, such as access to health care may facilitate early diagnosis and treatment and account in part for the varying incidence of hearing deficit among the various centres.

ACKNOWLEDGEMENTS: The authors thank Susan Richardson, MD, for providing data on Haemophilus influenzae beta-lactamase positivity rate, and Helen Heurter, BScN, for help in reviewing the patients charts.

\section{REFERENCES}

1. Feigin RD. Bacterial meningitis beyond the neonatal period. In: Feigin RD, Cherry JD, eds. Textbook of Pediatric Infectious Diseases, 2nd edn. Philadelphia: Saunders, 1987:439-65.

2. Schlech WF III, Ward JI, Band JD, et al. Bacterial meningitis in the United States, 1978 through 1981 JAMA 1985;253:1749-54.

3. Klein JO, Feigin RD, McCracken GH Jr. Report of the task force on diagnosis and management of meningitis. Pediatrics 1986;78:959-82. 
4. Sell SH. Long term sequelae of bacterial meningitis in children. Pediatr Infect Dis J 1983:2:90-3.

5. Pomeroy SL, Holmes SJ, Dodge PR, Feigin RD. Seizures and other neurologic sequelae of bacterial meningitis in children. N Engl J Med 1990;323:1651-7.

6. Taylor GH, Mills EL, Giampi A, et al. The sequelae of Haemophilus influenzae meningitis in school-age children. N Engl J Med 1990;323:1657-63.

7. Dodge PR, Davis H, Feigin RD, et al. Prospective evaluation of hearing impairment as sequelae of acute bacterial meningitis. N Engl J Med 1984;31 1:869-74.

8. Lebel MH, McCracken GH Jr. Delayed cerebrospinal fluid sterilization and adverse outcome of bacterial meningitis in infants and children. Pediatrics 1989;83:161-7.

9. Schaad UB, Suter S, Gianella-Borradori A, et al. A comparison of ceftriaxone and cefuroxime for the treatment of bacterial meningitis in children. N Engl J Med 1990:322:141-7.

10. Jadavji T, Biggar WD, Gold R, et al. Sequelae of acute bacterial meningitis in children treated for seven days. Pediatrics 1986;78:21-5.

11. Peltola H, Anttila M, Renkonen O, et al. Randomized comparison of chloramphenicol, ampicillin, cefotaxime, and ceftriaxone for childhood bacterial meningitis. Lancet 1989;i:1281-7.

12. Rodriguez W, Khan WN, Gold B, et al. Ceftazidime in the treatment of meningitis in infants and children over one month of age. Am J Med 1985;79(2A):52-5.

13. Marks WA, Studman HR, Marks MI, et al. Cefuroxime versus ampicillin plus chloramphenicol in childhood bacterial meningitis: A multicenter randomized controlled trial. J Pediatr 1986;109:123-30.

14. Lebel MH, Hoym MJ, McCracken GH Jr. Comparative efficacy of ceftriaxone and cefuroxime for treatment of bacterial meningitis. J Pediatr 1989; 114:1049-54.

15. Hatch DL, Overturf GD. Delayed cerebrospinal fluid sterilization in infants with Haemophilus influenzae type b meningitis. J Infect Dis 1989;160:711-5.

16. Infectious Diseases and Immunization Committee, Canadian Paediatric Society. Initial therapy for bacterial meningitis. Can Med Assoc J 1990;142:305-6.

17. Sande MA, Tauber MG, Scheld WM, et al. Report of a second workshop: Pathophysiology of bacterial meningitis. Pediatr Infect Dis J 1989;8:919-21. 


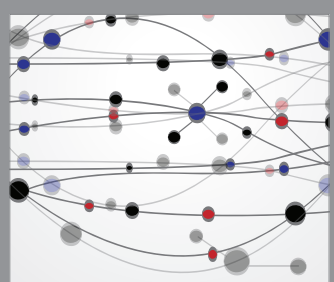

The Scientific World Journal
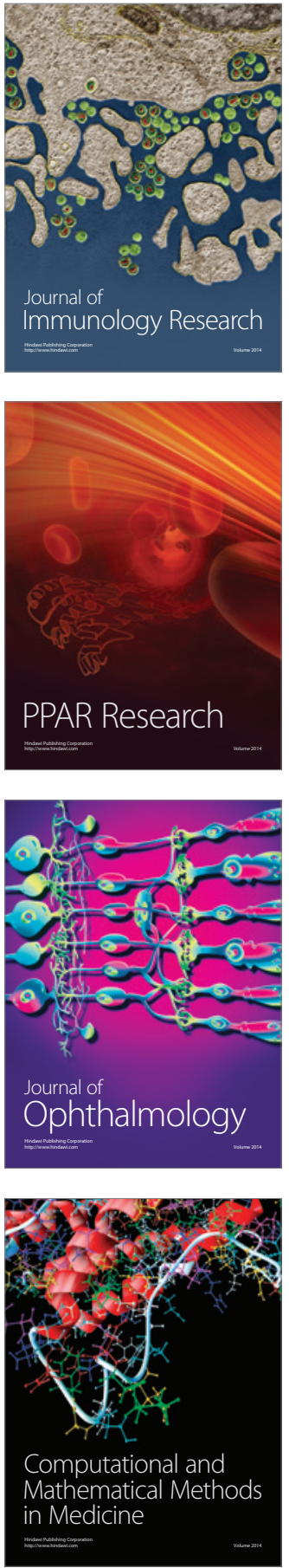

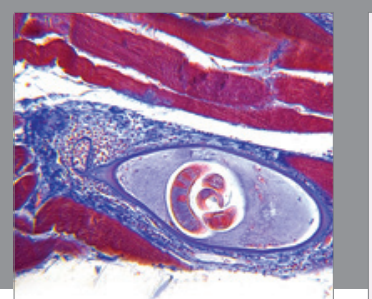

Gastroenterology Research and Practice

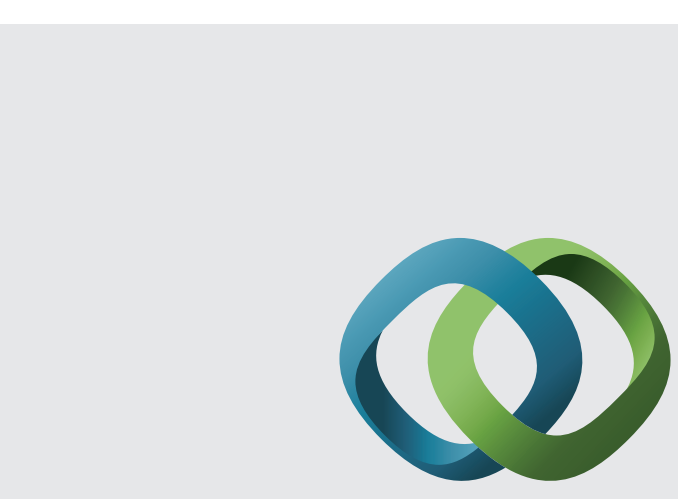

\section{Hindawi}

Submit your manuscripts at

http://www.hindawi.com
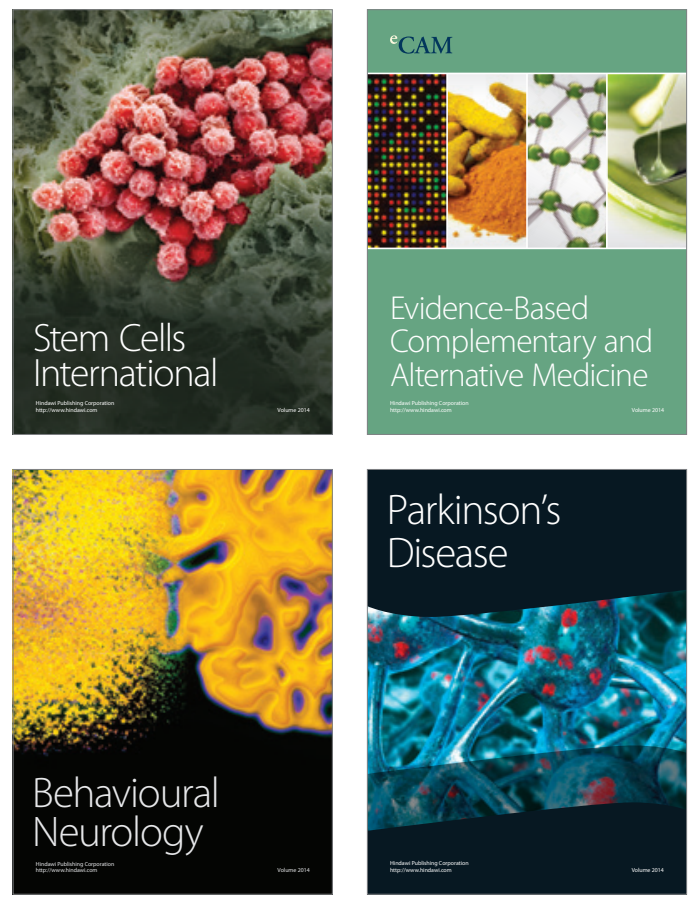
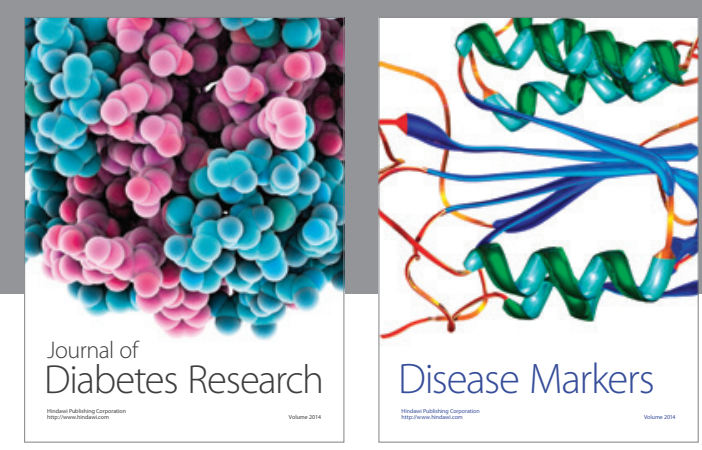

Disease Markers
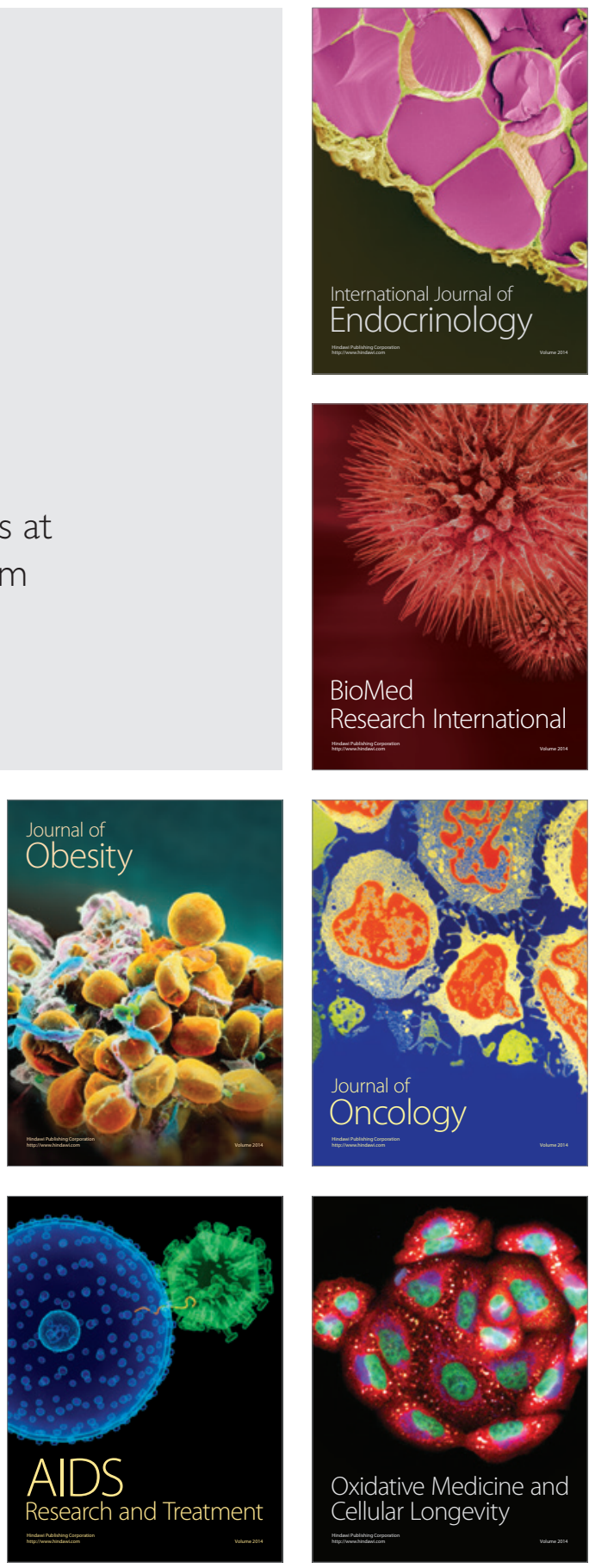